\title{
EFFECTS OF EXOGENOUS AND ENDOGENOUS POSTERIOR PITUITARY ANTIDIURETIC HORMONE ON WATER AND ELECTROLYTE EXCRETION ${ }^{1}$
}

\author{
By RICHARD J. F. MURPHY 2 AND EUGENE A. STEAD, JR. \\ (From the Department of Medicine, Duke University School of Medicine, Durham, N. C.)
}

(Submitted for publication March 23, 1951; accepted July 30, 1951)

The urine output of normal subjects varies greatly from hour to hour. Two of the important factors affecting the urine volume are the degree of activity of the posterior pituitary gland and the amount of solids to be excreted in the urine. In general, whenever the normal kidney is excreting a concentrated urine of low volume, secretion of the antidiuretic hormone $(\mathrm{ADH})$ of the posterior pituitary gland is occurring. This secretion may be due to emotional, drug, or other nervous stimulation, or to an increased osmotic pressure in the extracellular fluid. The excretion of a large amount of very dilute urine by the normal kidney occurs when ADH production is inhibited either by nervous or osmotic stimuli. When concentrated electrolyte solutions are administered intravenously, a large quantity of concentrated urine is produced. This large urine volume appears to be the result of the osmotic effects of the solids in the urine, and the volume is not decreased by secretion of $\mathrm{ADH}$.

While there is general agreement as to the effects of $\mathrm{ADH}$ on water excretion, there has been little information on its effects on sodium, chloride and potassium excretion in man. The purposes of this study were (1) to determine the effect of endogenously produced $\mathrm{ADH}$ on the excretion of water, sodium and chloride, (2) to determine whether minute doses of commercial Pitressin given intravenously had the same effects on water and electrolyte excretion as endogenously produced ADH, (3) to determine whether the rate of excretion of sodium modified the antidiuretic effectiveness of Pitressin, and (4) to determine whether Pitressin given intravenously in minute doses altered glomerular filtration rate or renal plasma flow.

\footnotetext{
1 This work was supported by a grant from the Life Insurance Medical Research Fund and the Anna $H$. Hanes Memorial Fund.

2 Present Address: Department of Medicine, Royal Victoria Hospital, Montreal, Canada.
}

\section{MATERIALS AND METHODS}

All of the following studies have been carried out on human subjects without endocrine, renal, cardiac, or other disease which has a known effect on water and electrolyte metabolism. All had been on normal salt and water intakes in the past. All subjects were studied in the post-absorptive state as regards food. The differing water and electrolyte conditions which were introduced as a part of the study will be mentioned specifically in the results.

In all studies the same lot of Pitressin (commercial ADH prepared by Parke, Davis and Company) has been used. Fresh solutions of Pitressin in $.9 \% \mathrm{NaCl}$ were prepared for each experiment. The doses varied somewhat as specifically mentioned but where it is not mentioned, the dose was arbitrarily fixed at $\mathbf{1 . 0}$ milliunit per kilo of body weight.

Urine collections were made from an indwelling urethral catheter which was placed at the bladder neck with considerable care. Throughout the full period of each study, which was carried out in a quiet, isolated environment, the patient was recumbent but not sleeping. As much assurance as possible was given to avoid any emotional upset during the simple procedures that were carried out.

In all cases except the clearance studies, urine was collected at arbitrary time intervals of 10 minutes. Individual samples were measured for chloride by the Van Slyke and Hiller modification of the method of Sendroy (1). Sodium and potassium were measured with the Perkin-Elmer flame photometer.

In measuring the renal hemodynamic effect of Pitressin, the clearance techniques of Smith, Goldring, and Chasis have been followed using inulin and sodium paraminohippurate (PAH) as the test substances (2).

\section{RESULTS}

Endogenous secretion of pituitary $A D H$. After collecting urine for 20-30 minutes, sodium chloride solution in doses of 20-30 cc. per kilo of body weight was given intravenously over a period of 30-60 minutes to 21 normal subjects. These individuals may be divided into two groups, depending on the concentration of the salt used. Group I consisted of 15 subjects who received a solution with a concentration of 125-146 millimols of sodium chloride; Group II of six subjects who re- 


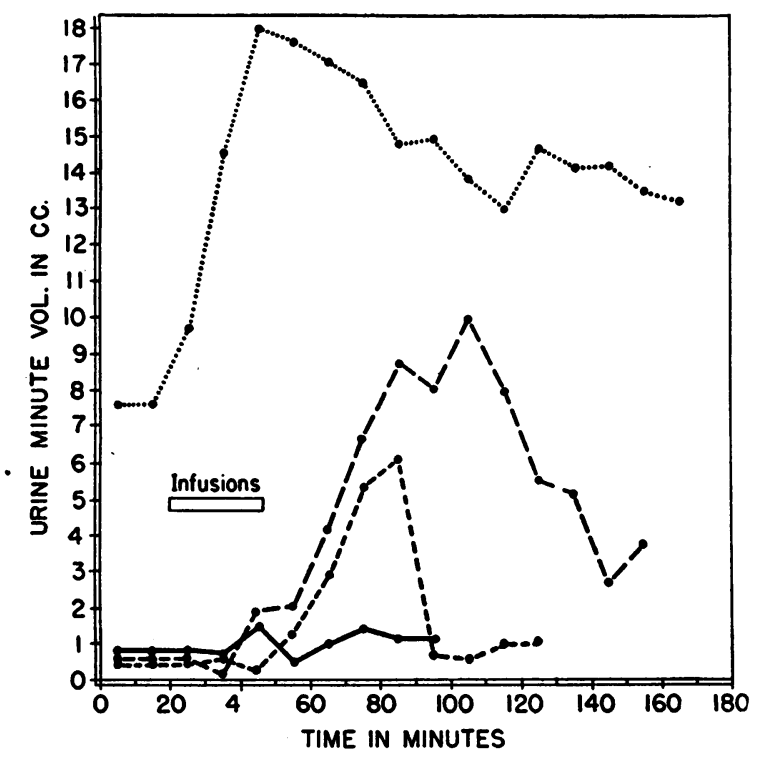

Fig. 1. Effect of NaCl Infusions on Urine Volume in Three Normal Subjects and One Patient with Diabetes Insipidus

The findings in normal subjects are shown in the three lower curves. The subjects receiving $\mathrm{NaCl}$ solution of 155 millimols are represented by the continuous line; that of 142 millimols by short dashes; and that of 125 millimols by long dashes. The concentration of the $\mathrm{NaCl}$ solution in the patient with diabetes insipidus was 139 millimols (dotted line).

ceived a solution with a concentration of 149-155 millimols. It is generally stated that $.9 \%$ sodium chloride solution (155 millimols) is isotonic with plasma.

In Group I the initial effect was the production of a water diuresis (i.e., the urine minute volumes increased markedly to levels of $6-12 \mathrm{cc} . / \mathrm{min}$. and sodium and chloride concentrations decreased) beginning about 30 minutes after the infusion was started. After a variable but short period of time there was an abrupt antidiuresis. As shown in Figure 1, the more concentrated solutions in Group I produced an earlier antidiuresis. In Group II, who received saline in slightly greater concentration, no water diuresis was produced. The urine volume increased slowly over the period of observation but it did not rise above $3 \mathrm{cc}$. $/ \mathrm{min}$., and there was no abrupt antidiuresis. As the urine volume increased in this group the sodium concentration in the urine rose and did not decrease as it did in Group I. In Figure 1 the effect of giving $1,400 \mathrm{cc}$. of sodium chloride solution with a concentration of 139 millimols to a patient with diabetes insipidus is shown. There was an immediate large increase in urine volume with a slow fall over the next two hours. There was no abrupt antidiuresis as there was in Group I.

The following interpretation of these data is offered: Solutions containing a concentration of between 125 and 146 millimols of sodium chloride do not stimulate the production of $\mathrm{ADH}$. Their initial effect is to cause a water diuresis either by dilution of existing ADH or by inhibition of its secretion. During water diuresis the loss of water greatly exceeds the loss of salt and the electrolytes in the body are concentrated. In due time this causes an osmotic stimulus for ADH secretion and antidiuresis occurs. The absence of a water diuresis when the concentration of sodium chloride is slightly increased in the fluid administered suggests that the osmotic mechanism is a sensitive one and that the amount of water lost does not have to be large to cause the production of endogenous $\mathrm{ADH}$. As the concentration of the $\mathrm{NaCl}$ solution approaches 150 millimols, the duration of the water diuresis is progressively reduced (Figure 1). The fact that the patient with diabetes insipidus

TABLE I

Transition from diuresis to antidiuresis following infusion of $\mathrm{NaCl}$ solution of concentration $125-146 \mathrm{mM}$. Lack of effect on excretion of sodium and chloride

\begin{tabular}{|c|c|c|c|c|c|c|c|c|c|c|c|c|c|c|c|c|c|c|c|c|c|}
\hline \multirow{2}{*}{$\begin{array}{l}\text { Subj. } \\
\text { D. A. } \\
\text { W. M. } \\
\text { H. C. } \\
\text { E. T. } \\
\text { G. H. } \\
\text { E. A. } \\
\text { A. M. } \\
\text { E. T. }\end{array}$} & \multicolumn{7}{|c|}{ Water excretion (cc./min.) } & \multicolumn{7}{|c|}{ Chloride excretion (meq./10 min.) } & \multicolumn{7}{|c|}{ Sodium excretion (meq./10 min.) } \\
\hline & $\begin{array}{r}10.8 \\
7.5 \\
4.0 \\
15.7 \\
12.5 \\
14.0 \\
13.2 \\
9.8\end{array}$ & $\begin{array}{r}9.0 \\
12.6 \\
5.6 \\
13.5 \\
15.4 \\
13.4 \\
13.3 \\
8.5\end{array}$ & $\begin{array}{r}8.1 \\
12.8 \\
4.7 \\
9.4 \\
8.2 \\
11.8 \\
14.1 \\
6.3\end{array}$ & $\begin{array}{r}7.2 \\
8.5 \\
4.5 \\
8.7 \\
4.5 \\
9.5 \\
10.7 \\
3.7\end{array}$ & $\begin{array}{l}3.8 \\
4.5 \\
2.9 \\
8.0 \\
4.6 \\
6.2 \\
4.2 \\
2.6\end{array}$ & $\begin{array}{l}2.8 \\
3.5 \\
2.4 \\
5.5 \\
5.2 \\
5.1 \\
3.2 \\
2.7\end{array}$ & $\begin{array}{l}3.5 \\
2.9 \\
2.4 \\
5.8 \\
5.4 \\
3.9 \\
3.5 \\
2.6\end{array}$ & $\begin{array}{l}7.0 \\
4.5 \\
1.6 \\
4.4 \\
6.8 \\
4.5 \\
5.3 \\
2.3\end{array}$ & $\begin{array}{l}7.0 \\
7.1 \\
1.8 \\
4.4 \\
7.1 \\
4.6 \\
4.5 \\
2.0\end{array}$ & $\begin{array}{l}6.6 \\
6.3 \\
1.7 \\
4.2 \\
6.9 \\
4.6 \\
4.9 \\
1.9\end{array}$ & $\begin{array}{l}6.5 \\
5.4 \\
2.1 \\
4.5 \\
6.6 \\
4.5 \\
5.0 \\
1.7\end{array}$ & $\begin{array}{l}5.1 \\
6.2 \\
2.7 \\
4.6 \\
7.6 \\
4.2 \\
4.2 \\
1.7\end{array}$ & $\begin{array}{l}4.3 \\
5.9 \\
2.5 \\
3.6 \\
7.8 \\
4.3 \\
4.8 \\
1.8\end{array}$ & $\begin{array}{l}5.3 \\
5.4 \\
3.0 \\
4.8 \\
7.9 \\
4.3 \\
5.1 \\
1.9\end{array}$ & $\begin{array}{l}7.8 \\
3.4 \\
2.2 \\
5.4 \\
7.4 \\
3.2 \\
5.7 \\
2.0\end{array}$ & $\begin{array}{l}6.9 \\
6.1 \\
2.2 \\
5.5 \\
6.9 \\
3.0 \\
4.9 \\
1.6\end{array}$ & $\begin{array}{l}5.8 \\
5.5 \\
2.0 \\
4.8 \\
7.3 \\
3.1 \\
5.2 \\
1.8\end{array}$ & $\begin{array}{l}6.4 \\
4.4 \\
2.4 \\
5.4 \\
7.4 \\
3.0 \\
6.0 \\
1.8\end{array}$ & $\begin{array}{l}5.3 \\
5.6 \\
3.2 \\
5.7 \\
8.4 \\
2.9 \\
4.6 \\
1.8\end{array}$ & \begin{tabular}{|l|}
4.4 \\
5.4 \\
3.1 \\
4.3 \\
9.7 \\
2.6 \\
5.9 \\
1.9
\end{tabular} & $\begin{array}{l}5.4 \\
4.7 \\
3.1 \\
5.9 \\
8.3 \\
2.9 \\
6.3 \\
2.0\end{array}$ \\
\hline
\end{tabular}


TABLE II

Effect of small, intravenous doses of Pitressin on urine volume and sodium and chloride excretion in the absence of endogenous secretion of $A D H$ Observations were made during infusion of $\mathrm{PAH}$ and insulin

\begin{tabular}{|c|c|c|c|c|c|c|c|c|c|c|c|c|}
\hline \multirow{3}{*}{ Subj. } & \multicolumn{4}{|c|}{ Urine volume $(c c . / m i n)}$. & \multicolumn{4}{|c|}{ Urine chloride (meq./min.) } & \multicolumn{4}{|c|}{ Urine sodium ( $\mu$ eq./min.) } \\
\hline & \multicolumn{2}{|c|}{$\begin{array}{c}\text { Before } \\
\text { Pitressin }\end{array}$} & \multicolumn{2}{|c|}{$\begin{array}{c}\text { After } \\
\text { Pitressin }\end{array}$} & \multicolumn{2}{|c|}{$\begin{array}{c}\text { Before } \\
\text { Pitressin }\end{array}$} & \multicolumn{2}{|c|}{$\begin{array}{c}\text { After } \\
\text { Pitressin }\end{array}$} & \multicolumn{2}{|c|}{$\begin{array}{c}\text { Before } \\
\text { Pitressin }\end{array}$} & \multicolumn{2}{|c|}{$\begin{array}{c}\text { After } \\
\text { Pitressin }\end{array}$} \\
\hline & Per. I & Per. II & Per. I & Per. II & Per. I & Per. II & Per. I & Per. II & Per. I & Per. II & Per. I & Per. II \\
\hline $\begin{array}{l}\text { D. W. } \\
\text { M. B. } \\
\text { L. C. } \\
\text { E. M. } \\
\text { L. H. } \\
\text { R. T. } \\
\text { M. C. } \\
\text { H. R. } \\
\text { R. T. }\end{array}$ & $\begin{array}{r}9.6 \\
9.6 \\
6.8 \\
10.2 \\
14.6 \\
12.3 \\
17.1 \\
8.2 \\
10.9\end{array}$ & $\begin{array}{r}12.0 \\
10.1 \\
8.3 \\
12.2 \\
14.9 \\
13.8 \\
17.7 \\
6.2 \\
11.5\end{array}$ & $\begin{array}{l}1.9 \\
2.0 \\
0.2 \\
0.3 \\
0.8 \\
1.1 \\
0.3 \\
2.3 \\
1.0\end{array}$ & $\begin{array}{l}2.2 \\
2.1 \\
0.8 \\
0.8 \\
1.3 \\
0.4 \\
1.4 \\
2.5 \\
1.0\end{array}$ & $\begin{array}{r}73 \\
135 \\
42 \\
80 \\
185 \\
123 \\
322 \\
309 \\
141\end{array}$ & $\begin{array}{r}70 \\
154 \\
53 \\
80 \\
162 \\
151 \\
296 \\
277 \\
139\end{array}$ & $\begin{array}{r}82 \\
250 \\
49 \\
58 \\
123 \\
123 \\
218 \\
305 \\
144\end{array}$ & $\begin{array}{r}62 \\
290 \\
64 \\
57 \\
110 \\
90 \\
254 \\
235 \\
119\end{array}$ & $\begin{array}{r}119 \\
133 \\
41 \\
94 \\
257 \\
143 \\
411 \\
366 \\
128\end{array}$ & $\begin{array}{r}89 \\
157 \\
69 \\
94 \\
221 \\
171 \\
389 \\
336 \\
138\end{array}$ & $\begin{array}{r}133 \\
225 \\
49 \\
68 \\
139 \\
143 \\
241 \\
391 \\
117\end{array}$ & $\begin{array}{r}107 \\
308 \\
79 \\
66 \\
143 \\
89 \\
291 \\
324 \\
103\end{array}$ \\
\hline
\end{tabular}

did not have the abrupt antidiuresis which the normal subjects had supports the above interpretation. O'Connor (3) has shown that in the dog changes between a fall of $2.5 \%$ and an increase of $5 \%$ from the resting level of blood chloride were sufficient to cause the tubules to respond over the full range of their functional capacity from maximal selective reabsorption of water when salt was given to minimal reabsorption in water diuresis.

Granting that the antidiuresis produced when $\mathrm{NaCl}$ solutions between 125 and 146 millimols are given intravenously results from the secretion of endogenous $\mathrm{ADH}$, we are in a position to determine the effect of this material on electrolyte excretion. Table I shows these results in eight normal subjects in whom complete data on sodium and chloride excretion are available. Despite a change in urine volume from a mean of $11 \mathrm{cc} . / \mathrm{min}$. to $3.8 \mathrm{cc} . / \mathrm{min}$. the excretion of sodium and chloride remained constant. Under the conditions of these observations endogenous $\mathrm{ADH}$ neither increases nor decreases sodium and chloride excretion.

\section{EFFECT OF MINUTE DOSES OF PITRESSIN ON THE EXCRETION OF WATER AND ELECTROLYTES}

Shannon has shown that the full range of antidiuretic effects can be produced in the intact dogs by the intravenous administration of 1-5 milliunits of Pitressin per hour (4). Lauson and his colleagues reported identical findings in man with allowance for weight differences (5). In the dog (6) and presumably in man, much greater quantities of $\mathrm{ADH}$ are produced in response to certain physiologic stimuli than are needed for maximal antidiuretic activity. In five normal subjects the endogenous secretion of $\mathrm{ADH}$ was reduced to a minimum by oral administration of $1,000-2,000$ cc. of water and the antidiuretic effects of giving a single intravenous injection of 5 to 70 milliunits of Pitressin were observed (Figure 2). If one allows five minutes as an average figure for the passage of urine from the renal tubules to the bladder, it appears that the antidiuretic effect is produced immediately. It is also apparent that over a fairly wide range of this drug, the duration of maximal antidiuresis is relatively fixed. In

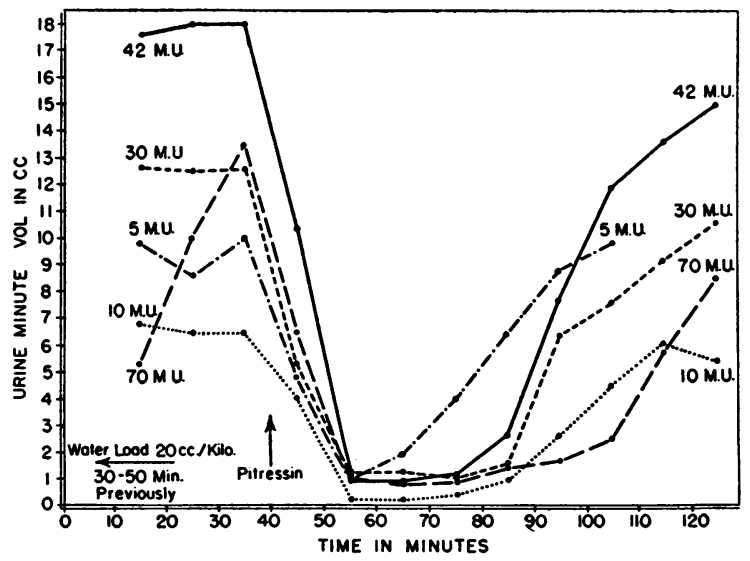

Fig. 2. Effect of Small Varying Doses of PitresSIN ON the Course of Water DiUREsis in Normal SUBJECTS

Each point represents the average minute volume of a 10 minute collection period and is placed at the five minute point in the period. 
four of these five subjects receiving doses varying from 10-70 milliunits, maximal antidiuresis lasted about 40 minutes and an additional $30-40$ minutes were required for the tubules to "escape" from the antidiuretic effect. In the one subject receiving only 5 milliunits, onset of maximal antidiuresis was similar to the other individuals but the duration of maximal antidiuresis was shorter and the "escape" from its effect more immediate.

Doses of 0.5 to 2 milliunits of Pitressin per kilo of body weight given intravenously over a two minute period of time produced no detectable effect on pulse rate, blood pressure, skin color, or gastrointestinal activity.

The effect of Pitressin on electrolyte excretion was measured under three differing circumstances. The first was in conjunction with the study of renal blood flow and glomerular filtration rate. These subjects were previously water-loaded to suppress endogenous secretion of $\mathrm{ADH}$. It has been stated that in dogs, this is the only way to demonstrate the "chloruretic" properties of this preparation (7). All these subjects were given a standard volume of water to drink (20 cc. per kilo of body weight) $30-50$ minutes before the onset of the studies so that they had a good water diuresis by the time the pre-Pitressin collections were made. These measurements were made during the infusion of inulin and PAH. Hippurate, being an acid salt which is rapidly cleared by the tubules, has an effect on the excretion of sodium. This effect was present in the study periods before and after the injection of Pitressin. The data are recorded in Table II and the values are expressed in terms of excretion per minute because the time of the individual periods ranged from 13-18 minutes. Despite the striking change in urine volume from $11.0 \pm 1.1 \mathrm{cc}$. and $11.9 \pm 1.1 \mathrm{cc}$. in the two periods before Pitressin to $1.1 \pm 0.3 \mathrm{cc}$. and $1.4 \pm 0.2 \mathrm{cc}$. in the two periods after Pitressin the excretion of sodium and chloride was not significantly changed. Potassium excretion was not measured in this group.

The second group of seven subjects received a water load of $20 \mathrm{cc}$. per kilo of body weight. They differed from the first group in that they had had no injections of inulin or hippurate. A 30 minute collection of urine was made before and after the injection of Pitressin. The urine was not collected during the first 10 minutes after the injection of Pitressin. In this group there was a slight but constant decrease in the excretion of sodium. The excretion of chloride in those cases where it was measured followed sodium. Potassium excretion was not measured. The data are recorded in Table III.

The third group of eight subjects received 1,0001,500 cc. of $0.8-0.9 \% \mathrm{NaCl}$ solution intravenously before urine collections were started. The infusion was finished one to two hours before Pitressin was given. This insured a relatively high concentration of sodium and chloride in the urine. These patients undoubtedly had some endogenous $\mathrm{ADH}$ effect because the urine volume was considerably smaller than in the previous study. They received no inulin or hippurate. In this group, urine collections were made at 10 minute intervals to note any pattern responses. Figure 3 shows the effect

TABLE III

Differing effects on sodium excretion of small doses of intravenous Pitressin in two groups, one excreting small amount of salt in large volume of urine and the other excreting larger amount of salt in a smaller volume of urine

Each figure represents the average of a 30 minute collection period

\begin{tabular}{|c|c|c|c|c|c|c|c|c|c|}
\hline \multicolumn{5}{|c|}{ A. Water load } & \multicolumn{5}{|c|}{ B. Saline load } \\
\hline \multicolumn{3}{|c|}{$\begin{array}{l}\text { Urine volume } \\
\text { (cc./min.) }\end{array}$} & \multicolumn{2}{|c|}{$\begin{array}{l}\text { Sodium excretion } \\
\text { (meq./min.) }\end{array}$} & \multicolumn{3}{|c|}{$\begin{array}{l}\text { Urine volume } \\
\text { (cc./min.) }\end{array}$} & \multicolumn{2}{|c|}{$\begin{array}{l}\text { Sodium excretion } \\
\text { (meq./min.) }\end{array}$} \\
\hline Subj. & $\begin{array}{l}\text { Before } \\
\text { Pitressin }\end{array}$ & $\begin{array}{c}\text { After } \\
\text { Pitressin }\end{array}$ & $\begin{array}{l}\text { Before } \\
\text { Pitressin }\end{array}$ & $\begin{array}{l}\text { After } \\
\text { Pitressin }\end{array}$ & Subj. & $\begin{array}{c}\text { Before } \\
\text { Pitressin }\end{array}$ & $\begin{array}{c}\text { After } \\
\text { Pitressin }\end{array}$ & $\begin{array}{c}\text { Before } \\
\text { Pitressin }\end{array}$ & Pitressin \\
\hline $\begin{array}{l}\text { H. C. } \\
\text { C. I. } \\
\text { M. J. } \\
\text { D. B. } \\
\text { A. W. } \\
\text { A. D. } \\
\text { A. M. }\end{array}$ & $\begin{array}{r}10.5 \\
18.2 \\
5.7 \\
6.6 \\
11.0 \\
9.5 \\
9.6\end{array}$ & $\begin{array}{l}1.2 \\
1.0 \\
0.3 \\
0.3 \\
1.3 \\
2.4 \\
0.9\end{array}$ & $\begin{array}{l}.084 \\
.109 \\
.040 \\
.007 \\
.132 \\
.143 \\
.211\end{array}$ & $\begin{array}{l}.078 \\
.069 \\
.029 \\
.003 \\
.127 \\
.134 \\
.157\end{array}$ & $\begin{array}{l}\text { A. M. } \\
\text { H. C. } \\
\text { E. T. } \\
\text { M. M. } \\
\text { H. L. } \\
\text { E. A. } \\
\text { G. H. }\end{array}$ & $\begin{array}{l}2.9 \\
2.4 \\
4.7 \\
5.5 \\
6.9 \\
3.1 \\
5.1\end{array}$ & $\begin{array}{l}1.7 \\
2.2 \\
2.6 \\
2.8 \\
4.1 \\
2.0 \\
2.3\end{array}$ & $\begin{array}{l}.67 \\
.35 \\
.57 \\
.51 \\
.55 \\
.27 \\
.85\end{array}$ & $\begin{array}{l}44 \\
39 \\
47 \\
52 \\
72 \\
27 \\
51\end{array}$ \\
\hline
\end{tabular}




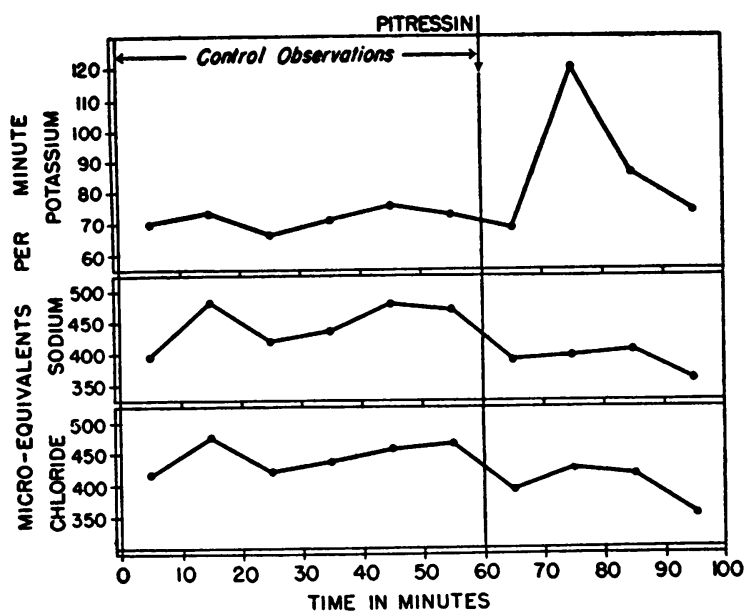

Fig. 3. The Effect of Pitressin (1 Milliunit Per Kilo Intravenously) on the Excretion of Sodium, Chloride, and Potassium

There was a significant change in potassium excretion $(P<.02)$.

of intravenous Pitressin on the excretion of sodium, chloride, and potassium. The sodium and chloride excretion in this group previous to Pitressin was approximately three times as large as in the water diuresis group. The excretion of sodium and chloride was not significantly changed by Pitressin. Potassium excretion showed a highly significant increase in the group from a mean of $70 \pm 10 \cdot$ microequivalents per minute to $120 \pm$ 14 in the first $10-20$ minutes following Pitressin administration. In the two following 10 minute periods, potassium excretion began to return toward the control values. Observations on the effect of Pitressin on potassium excretion after water loading were not made.

Effect of sodium chloride excretion on water excretion after Pitressin. Table III compares the urine volume after Pitressin in two groups of individuals. Group $A$ had received a water load of 20 cc. per kilo of body weight, and Group B had been given $0.8-0.9 \% \mathrm{NaCl}$ solution as described above. The chief distinguishing features between the two groups so far as this point is concerned is that the water-loaded individuals were excreting relatively small amounts of salt in a large volume of water and the group who had received intravenous saline were excreting considerably larger quantities of salt in smaller amounts of water. Observation periods were 30 minutes before Pitressin and 30 minutes after Pitressin. From the previous studies, this was felt to be within the limits of the period of maximal antidiuresis. In all cases, a 10 minute period was allowed to elapse after the administration of Pitressin to correct for renal tubule to bladder delay. The dose of Pitressin in the saline group was constant, 1.0 milliunits per kilo. In the water group in some cases, it was less, but never more. The mean urine minute volume expressed in $\mathrm{cc} . / \mathrm{min}$. for the 30 minute period in the saline group following Pitressin was $2.5 \pm 0.29$, and for the water group, 1.06 \pm 0.27 . Comparing these two groups statistically, the difference is of significance with a $p$ value equal to 0.01 . In terms of Pitressin effect, the experiment was weighted against the results because in some of the water experiments, Pitressin dosage was less than 1.0 milliunit per kilo. We take these results to indicate that changes in sodium excretion of a degree that is well within the average physiological range, has a modifying influence on the antidiuretic effectiveness of Pitressin.

Effect of Pitressin on renal hemodynamics. In dogs and rats no consistent effect has been found on renal blood flow and glomerular filtration rate $(8,9)$. Table IV shows the effect of intravenous Pitressin on these same functions in normal subjects. All studies were prepared and carried through under identical conditions. All subjects were given a similar amount of water to drink previous to starting the clearances $(20 \mathrm{cc}$. per kilo of body weight) to suppress endogenous $\mathrm{ADH}$. Following the initial control period (two clearances), all received intravenous Pitressin in the dose of 1 milliunit per kilo of body weight. A pe-

TABLE IV

The effect of intravenous Pitressin on renal plasma flow and glomerular filtration rate in normal subjects

\begin{tabular}{l|c|c|c|c}
\hline & \multicolumn{2}{|c|}{ CIN. (cc./min.) } & \multicolumn{2}{|c}{ C CAB (cc./min.) } \\
\cline { 2 - 5 } Subj. & Before & After & Before & After \\
\hline R. T. & 131 & 116 & 752 & 718 \\
M. C. & 141 & 132 & 650 & 587 \\
A. C. & 113 & 117 & 606 & 634 \\
L. C. & 102 & 106 & 472 & 455 \\
H. R. & 111 & 109 & 538 & 459 \\
R. T. & 115 & 118 & 738 & 674 \\
L. H. & 115 & 101 & 518 & 470 \\
E. M. & 111 & 110 & 539 & 381 \\
M. B. & 106 & 112 & 416 & 429 \\
D. W. & 85 & 99 & 504 & 556 \\
Mean & 113 & 112 & 573 & 536 \\
S. D. & 15.2 & 9.5 & 111 & 114 \\
S. E. & 4.8 & 3.0 & 35.2 & 36.1 \\
\hline
\end{tabular}


riod of 10-15 minutes was allowed before starting the first post-Pitressin period to allow for the mechanical effects of an abrupt change in urine volume to wear off. Then two or more additional clearance periods were carried out, each preceded by a similar dose of intravenous Pitressin to insure continuity of Pitressin effect. There was no demonstrable change in renal plasma flow and glomerular filtration rate.

\section{GENERAL DISCUSSION}

The data recorded here are consistent with the view that the physiologic effects of small doses of Pitressin on the excretion of water, sodium and chloride are quantitatively and qualitatively similar to those caused by endogenously produced $\mathrm{ADH}$. Observations of others comparing the antidiuresis caused by Pitressin with that produced by smoking support this thesis (10).

The effect of Pitressin on electrolyte excretion in the dog has not been consistent. O'Connor (3) found no effect on chloride excretion. Anslow and his colleagues (7) and Sartorius and Roberts (11) have shown that under certain conditions Pitressin causes a definite increase in sodium and chloride excretion in the dog. However, since in the latter studies Pitressin apparently increased glomerular filtration rate, these experiments probably cannot be directly applied to man.

In the experiments reported here there was no effect on the excretion of sodium and chloride in the water-loaded subjects receiving inulin and $\mathrm{PAH}$, and in the salt- and water-loaded subjects who did not receive inulin and PAH. In the water-loaded group who received no inulin or $\mathrm{PAH}$, there was a slight, but consistent, decrease in sodium excretion. The salt- and water-loaded subjects had a lower urine flow before Pitressin and a higher urine flow after Pitressin than the waterloaded group. It has been reported that Pitressin in man produces no change in the excretion of sodium chloride (10) and that it decreases the excretion of sodium slightly in the water-loaded subject (12). The latter authors believe that the reduction in the excretion of sodium is due to the low rate of urine flow which causes sodium to be more completely reabsorbed. Our data fit nicely into this hypothesis as the retention of sodium occurred only when the average excretion of water was reduced to $1 \mathrm{cc}$. $/ \mathrm{min}$.
The data in Table III show that a moderate increase in the rate of excretion of sodium chloride influences the volume of urine formed after Pitressin. The factors determining the rate of sodium chloride excretion seem to be little changed by $\mathrm{ADH}$, but under maximal ADH effect the amount of urine formed is greatly influenced by the amount of sodium chloride excreted. The mechanism by which increased sodium chloride excretion limits the antidiuretic effect of $\mathrm{ADH}$ remains to be determined. A simple osmotic effect of the salt rejected by the tubules seems the most likely explanation.

This dependence of water excretion on salt excretion has been studied in a different manner by Rosenbaum, Nelson and Strauss (13). They found a decreasing water excretion in the presence of a constant water load despite a constant filtration rate with the only variable being a diminishing sodium chloride excretion. Their results show that a maximum urine flow cannot be maintained without a considerable excretion of salt.

The increase in potassium excretion following Pitressin in the salt-loaded subjects was striking and immediate and suggests that it is caused by a change in renal tubular function. Assuming that Pitressin does affect the tubular mechanism responsible for potassium excretion, two possibilities exist since as Berliner, Kennedy and Hilton have shown potassium is both reabsorbed and excreted by the tubules (14). The tubular transport mechanism for reabsorption may be inhibited or the excretory mechanism intensified.

\section{CONCLUSIONS}

1. In normal subjects rapid intravenous infusion of saline with a concentration of 125-146 millimols $\mathrm{NaCl}$ produced a diuresis within 30 minutes which in terms of urine volume and sodium and chloride concentration is indistinguishable from a water diuresis.

2. After a short period of time this is succeeded by an abrupt antidiuresis due to posterior pituitary activity. Sodium and chloride excretion during this period is unchanged.

3. A comparison of the effects of Pitressin given intravenously and endogenously produced $\mathrm{ADH}$ was made in subjects receiving 0.8 to $0.9 \%$ saline solution. The effects on the excretion of water, sodium and chloride are similar. 
4. Commercial ADH (Pitressin) given intravenously in small doses causes a slight decrease in the excretion of sodium in water-loaded subjects in whom urine flow is reduced to around $1 \mathrm{cc} . / \mathrm{min}$. No effect was demonstrable in water-loaded subjects receiving inulin and $\mathrm{PAH}$ for clearance studies or in salt-loaded subjects. After salt loading Pitressin caused a transient increase in the excretion of potassium.

5. The urine volume after intravenous Pitressin is influenced by the excretion of amounts of sodium and chloride in the urine which are within the physiological range.

6. Small doses of Pitressin given intravenously have no effect on glomerular filtration rate and renal plasma flow.

\section{REFERENCES}

1. Hawk, P. B., Oser, B. L., and Summerson, W. H., Practical Physiological Chemistry. The Blakiston Company, Philadelphia, 1947, 12 Ed.

2. Smith, H. W., Goldring, W., and Chasis, H., The measurement of the tubular excretory mass, effective blood flow and filtration rate in the normal human kidney. J. Clin. Invest., 1938, 17, 263.

3. O'Connor, W. J., The role of the neurohypophysis of the dog in determining urinary changes, and the antidiuretic activity of urine, following the administration of sodium chloride or urea. Quart. J. Exper. Physiol., 1950, 36, 21.

4. Shannon, J. A., The control of the renal excretion of water. II. The rate of liberation of the posterior pituitary antidiuretic hormone in the dog. J. Exper. Med., 1942, 76, 387.

5. Lauson, H. D., Elder, H. A., Chinard, F. P., Cogzias,
G. C., and Greif, R. L., Estimation of the rate of antidiuretic hormone secretion in normal man. Federation Proc., 1948, 7, 69.

6. Ames, R. G., Moore, D. H., and van Dyke, H. B., The excretion of posterior antidiuretic hormone in the urine and its detection in the blood. Endocrinology, 1950, 46, 215.

7. Anslow, W. P., Jr., Wesson, L. G., Jr., Bolomey, A. A., and Taylor, J. G., Chloruretic action of pressorantidiuretic fraction of posterior pituitary extract. Federation Proc., 1948, 7, 3.

8. Corcoran, A. C., and Page, I. H., The effects of renin, Pitressin, and Pitressin and atropine on renal blood flow and clearance. Am. J. Physiol., 1939, 126, 354.

9. Dicker, S. E., and Heller, H., The renal action of posterior pituitary extract and its fractions as analysed by clearance experiments on rats. $\mathrm{J}$. Physiol., 1946, 104, 353.

10. Sinclair-Smith, B. C., Sisson, J., Kattus, A. A., Genecin, A., Monge, C., McKeever, W., and Newman, E. V., The effects of posterior pituitary extract and smoking on water, sodium and chloride excretion in normal subjects and in patients with congestive cardiac failure. Bull. Johns Hopkins Hosp., 1950, 87, 221.

11. Sartorius, O. W., and Roberts, K., The effects of pitressin and desoxycorticosterone in low dosage on the excretion of sodium, potassium, and water by the normal dog. Endocrinology, 1949, 45, 273.

12. Chalmers, T. M., Lewis, A. A. G., and Pawan, G. L. S., The effect of posterior pituitary extracts on the renal excretion of sodium and chloride in man. J. Physiol., 1951, 112, 238.

13. Rosenbaum, J. D., Nelson, W. P., III, and Strauss, M. D., The dependence of water diuresis upon electrolyte excretion. J. Clin. Invest., 1950, 29, 841.

14. Berliner, R. W., Kennedy, T. J., and Hilton, J. G., Renal mechanisms for excretion of potassium. Am. J. Physiol., 1950, 162, 348. 